Clinical data on patients positive for $S P_{1}$

\begin{tabular}{|c|c|c|c|c|c|}
\hline $\begin{array}{l}\text { Case } \\
\text { No }\end{array}$ & Treatment & $\begin{array}{l}\text { Calculated } \\
\text { day of } \\
\text { cycle }\end{array}$ & $\begin{array}{l}\text { Days } \\
\text { after } \\
\text { ovulation }\end{array}$ & $\underset{(\mu \mathbf{g} / \mathbf{l})}{\mathbf{S P}_{\mathbf{1}}}$ & $\begin{array}{l}\text { Type of } \\
\text { pregnancy }\end{array}$ \\
\hline 1 & $\begin{array}{l}\text { Human menopausal } \\
\text { and chorionic } \\
\text { gonadotrophin }\end{array}$ & 22 & 7 & $5 \cdot 0$ & Normal \\
\hline 2 & $\begin{array}{l}\text { Human menopausal } \\
\text { and chorionic } \\
\text { gonadotrophin }\end{array}$ & 21 & 8 & $5 \cdot 1$ & Twin \\
\hline 3 & Human chorionic & 23 & 9 & $8 \cdot 6$ & Normal \\
\hline 4 & $\begin{array}{l}\text { gonadotrophin } \\
\text { Human chorionic }\end{array}$ & 27 & 13 & $18 \cdot 5$ & Normal \\
\hline 5 & $\begin{array}{l}\text { gonadotrophin } \\
\text { Human menopausal } \\
\text { and chorionic } \\
\text { gonadotrophin }\end{array}$ & 27 & 13 & $19 \cdot 0$ & Normal \\
\hline 6 & $\begin{array}{l}\text { Human chorionic } \\
\text { gonadotrophin }\end{array}$ & 23 & 10 & $6 \cdot 8$ & Normal \\
\hline $\begin{array}{r}7 \\
8 \\
9 \\
10 \\
11 \\
12 \\
13 \\
14 \\
15 \\
16 \\
17 \\
18 \\
19 \\
20 \\
21 \\
22 \\
23 \\
24 \\
25 \\
26\end{array}$ & $\begin{array}{l}\text { AID } \\
\text { AID } \\
\text { AID } \\
\text { Clomiphene } \\
\text { Clomiphene } \\
\text { Clomiphene } \\
\text { Clomiphene } \\
\text { Clomiphene } \\
\text { Clomiphene } \\
\text { Nil } \\
\text { Nil } \\
\text { Nil } \\
\text { Nil } \\
\text { Nil } \\
\text { Nil } \\
\text { Nil } \\
\text { Nil } \\
\text { Nil } \\
\text { Nil } \\
\text { Nil }\end{array}$ & $\begin{array}{l}22 \\
21 \\
26 \\
21 \\
29 \\
22 \\
28 \\
27 \\
28 \\
22 \\
28 \\
29 \\
30 \\
28 \\
32 \\
30 \\
28 \\
27 \\
30 \\
30\end{array}$ & $\begin{array}{r}6 \\
6 \\
13 \\
8 \\
12 \\
10 \\
11 \\
9 \\
13 \\
6 \\
12 \\
14 \\
11 \\
12 \\
14 \\
13 \\
10 \\
10 \\
12 \\
13\end{array}$ & $\begin{array}{r}2 \cdot 8 \\
3 \cdot 5 \\
4 \cdot 4 \\
1 \cdot 8 \\
10 \cdot 4 \\
6 \cdot 8 \\
8 \cdot 9 \\
5 \cdot 2 \\
8 \cdot 6 \\
2 \cdot 2 \\
4 \cdot 4 \\
36 \cdot 0 \\
10 \cdot 0 \\
7 \cdot 2 \\
18 \cdot 0 \\
11 \cdot 7 \\
2 \cdot 2 \\
3 \cdot 5 \\
4 \cdot 1 \\
5 \cdot 1\end{array}$ & $\begin{array}{l}\text { Normal } \\
\text { Normal } \\
\text { Normal } \\
\text { Normal } \\
\text { Normal } \\
\text { Normal } \\
\text { Normal } \\
\text { Normal } \\
\text { Ectopic } \\
\text { Normal } \\
\text { Normal } \\
\text { Normal } \\
\text { Abortion } \\
\text { Abortion } \\
\text { Normal } \\
\text { Normal } \\
\text { Normal } \\
\text { Normal } \\
\text { Normal } \\
\text { Normal }\end{array}$ \\
\hline
\end{tabular}

AID = Artificial insemination from a donor

day of the test. The test does not require the use of radioactivity or expensive and sophisticated apparatus, is well within the compass of the ordinary clinical laboratory, and may be used when assays of $\beta$ chorionic gonadotrophin are unreliable.

In this investigation we were unable to determine the stage of gestation by which all tests yielded positive results; this question is pursued elsewhere. ${ }^{3}$ Our positive findings occurred in samples obtained at times ranging from the time of implantation to that of the first missed period; this is well in advance of what can be achieved by ordinary pregnancy tests or ultrasound.

No false positive results occurred, though it has been claimed that a few normal men and non-pregnant women have $\mathrm{SP}_{1}$ in their blood, ${ }^{4}$ as do some patients with malignant tumours. ${ }^{5}$ This is not a question of sensitivity, as many of the values found in non-pregnant subjects overlap values that we have found in women in early pregnancy. To some extent the difference may be accounted for in terms of methodology: other investigators have mostly used radioimmunoassay, and possibly enzyme immunoassay has less noise at the extremes of sensitivity than radioimmunoassay.

We are grateful to Dr F Dati of Behringwerke AG, Marburg, for the enzyme immunoassay kits, and to Miss Elaine Dalgarno for her secretarial help. AGA is in receipt of funding from the University of Assiut.

1 Grudzinskas JG, Lenton EA, Gordon YB, et al. Circulating levels of pregnancy-specific $\beta_{1}$-glycoprotein in early pregnancy. $\mathrm{Br} \mathcal{F}$ Obstet Gynaecol $1977 ; 84: 740-2$.

2 Dati F, Grenner G, Lüben G, et al. Comparison of enzyme immunoassays for pregnancy specific $\beta_{1}$-glycoprotein $\left(\mathrm{SP}_{1}\right)$ and $\alpha$-fetoprotein (AFP) with other immunochemical methods. Ric Clin Lab 1982;12:265-87.

${ }^{3}$ Ahmed AG, Klopper A. The diagnosis of early pregnancy by assay of placental proteins. Br $\mathcal{F}$ Obstet Gynaecol (in press).

4 Würz H. Serum concentrations of $S P_{1}$ (pregnancy specific glycoprotein) in healthy non-pregnant individuals and in patients with non-trophoblastic neoplasms. Arch Gynecol 1979;227:1-7.

- Searle F, Leake BA, Bagshawe KD, Dent J. Serum SP, (pregnancy specific $\beta_{1}$-glycoprotein) in choriocarcinoma and other neoplastic disease. Lancet 1978; i:579-80.

(Accepted 13 January 1983)

Department of Obstetrics and Gynaecology, University of Aberdeen, Royal Infirmary, Aberdeen AB9 2ZB

A G AHMED, MSC, MB, clinical research assistant

A KLOPPER, MD, FRCOG, professor of reproductive endocrinology

Correspondence to: Professor A Klopper.

\section{Simple and effective breast pump for nursing mothers}

The nutritive, immunological, and psychological advantages of breast $c$ feeding are well known. ${ }^{1-4}$ Many mothers, however, have great $\widehat{\triangle}$ difficulty breast feeding their newborn offspring directly, particularly $\bar{\Xi}$ when their infants are underweight or have some congenital mal- 7 formation. Hence it is especially desirable that these mothers should $\mathbb{D}$ provide freshly expressed breast milk to their infants, even if home $m$ duties limit their puerperal confinement.

Existing methods of expressing breast milk include manual and squeeze-bulb aspiration, laborious procedures that expose the milk to $\frac{\text { SO}}{+}$ air and surface contaminants. These manual methods are often rejected $\overrightarrow{0}$ as ineffective and time consuming. Modern postnatal wards are equipped with efficient but expensive electrical breast pumps that $\overline{\bar{p}}$ allow mothers to express their milk rapidly and aseptically. Mothers $\overrightarrow{\widetilde{d}}$ who have used these pumps successfully, however, often resort to $\varrho$ formula feeding on returning home.

I describe a simple breast pump which is portable, easy to operate, and inexpensive enough for home use but which has the efficiency? and safety features of the institutional machines.

\section{Bristol breast pump}

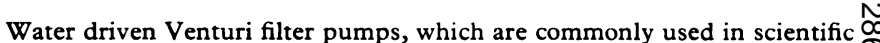
laboratories, provide a bench top vacuum source for filtering biological or chemical extracts. Suction pressures up to $200 \mathrm{mb}(150 \mathrm{~mm} \mathrm{Hg})$ may be $\omega$ generated using a water pressure of only $1.4 \mathrm{kgf} / \mathrm{cm}^{2}(27.8 \mathrm{psi})$, which is well $N$ below domestic supply pressures. Thus the evacuation capacity of a Venturi pump may exceed that of a typical $2800 \mathrm{rpm} 1 / 8 \mathrm{hp}$ electric pump. ${ }^{5}$

The Bristol breast pump (figure) is light and easy to hold and operate in one hand. The mother may freely adjust the suction pressure at the tap and 0 the rate of suckling with her fingertip. The standard $3.7 \mathrm{~cm}(1.5 \mathrm{in})$ thread of the baby bottle eliminates the usual need to transfer the expressed milk into another bottle, and the entire apparatus may be submerged in any $\frac{D}{O}$ available aqueous sterilising solution. Informal preliminary trials have given favourable results both in the home and at hospital, where some mothers $\rightarrow$ opted to use the water driven pump in preference to readily available electric machines.

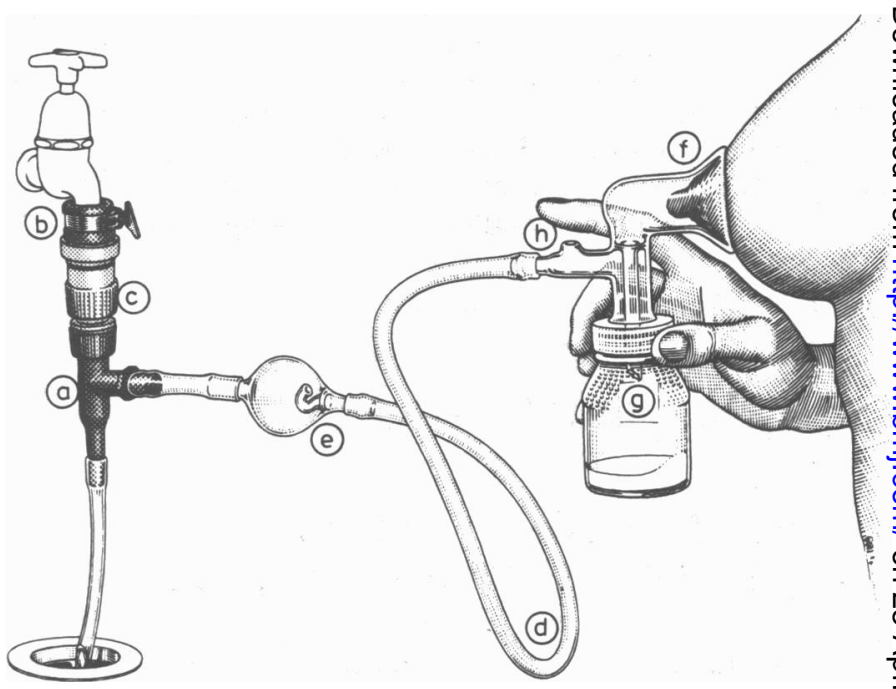

Breast milk collection system. Venturi pump (a) connected to water tap via $\widetilde{N}$ universal screw on adaptor (b), which may be left in place, and click on connector $(c)$ (Hozelock UK, Ltd), which allows easy removal of pump $\omega$ between feeds. Tubing $(d)$ transmits suction to milking apparatus, and safety $O$ trap (e) prevents backflow of water vapour. Breast cup $(f)$ is applied to areolar skin, and evacuation of milk bottle and breast cup achieved when valve $(h)$ is occluded by mother's finger. Expressed milk enters bottle via $\mathbb{D}$ internal channel $(g)$. Pulsatile sucking action is created by repeated light touch and release of finger valve.

\section{Comment}

In addition to providing natural food for a non-suckling newborn infant, an interval of breast milk expression may help overcome such 8 difficulties as inverted, flat, or sore nipples, insufficient or excessive lactation, milk retention, and maternal or infant illness or separation. The available electric breast pumps are complex and cumbersome. 
Their prohibitive cost is beyond the means of most small health centres and virtually all households (current price $£ 685.91$ including VAT for the Model 20 Egnell electric breast pump; Eschmann Bros and Walsh Ltd, Sussex). Yet it is in poorer communities that the potential need for such devices may be greatest.

The Bristol breast pump is simple both in design and in operation and should cost well under $£ 15$ if mass produced. It is easily sterilised and requires no maintenance. It affords the mother the freedom to select a comfortable suction pressure and to express milk at her own rate. Such a pump may provide a means for initiating, maintaining, or extending the lactational period in mothers who might otherwise resort to artificial infant formulas.

I thank the staff on ward 76 of Bristol Maternity Hospital, Mr R T Batchen for his indispensable glassblowing skills, Dr V M Sponsel for testing prototypes, and Gary $M$ James for the illustration.

This work has been supported by La Leche League International.

1 Vorherr H. Human lactation and breast feeding. In: Lactation: a comprehensive treatise. Vol 4. New York: Academic Press, 1978.

${ }^{2}$ Cunningham A. Morbidity in breast-fed and artificially fed infants. $\mathcal{f}$ Pediatr $1979 ; 95: 685-9$.

${ }^{3}$ Welsh J, May J. Anti-infective properties of breast milk. $\mathcal{F}$ Pediatr 1979 94:1-9.

${ }^{4}$ Klaus M, Kennel J. Maternal infant bonding. St Louis: C V Mosby Co, 1976.

${ }^{5}$ Gallenkamp. Scientific catalogue 1980. London: Gallenkamp, 1980:562-3.

(Accepted 17 fanuary 1983)

Department of Obstetrics and Gynaecology, University of Bristol Medical School, Bristol BS2 8BJ

WILLIAM E SPONSEL, BSC, clinical medical student

Correspondence to: 40 St John's Road, Clifton, Bristol BS8 2HG.

\section{Evidence that disopyramide does not interact with warfarin}

Haworth and Burroughs reported that disopyramide interacts with warfarin. ${ }^{1}$ Their observation was based on a single case where disopyramide was discontinued in a hypotensive patient because of its potential negative inotropic effect. A good clinical response occurred over 24 hours followed by a decreasing prothrombin time requiring incremental doses of warfarin. They concluded that the apparent interaction between disopyramide and warfarin might be a competitive phenomenon at the receptor site. Our findings refute their evidence.

\section{Present study and results}

We studied the doses of dicoumarol or warfarin in seven patients before and after conversion of atrial fibrillation (table). Two of the patients received dicoumarol and five warfarin. Quinidine sulphate was given to four of the patients (400 mg thrice daily) as an antiarrhythmic agent, while three-al receiving warfarin-were given disopyramide $(200 \mathrm{mg}$ thrice daily). With this treatment some patients regained sinus rhythm, and in the others sinus rhythm was regained after DC conversion. All except one of the patients needed a small increase in the weekly anticoagulant dose; the remaining patient had an increase in thrombotest value (table). (The dose was expressed as the mean number of tablets used weekly during five weeks before or five weeks after conversion. The dosage of oral anticoagulant drug was prescribed so that the thrombotest value was within therapeutic limits.)
After conversion of atrial fibrillation and start of quinidine or disopyramide an increase of about $10 \%$ was needed in the dose of dicoumarol or warfarin to keep the thrombotest value within the therapeutic range. Although the number of patients was small the same increase in anticoagulant dosage was required when patients were treated with either dicoumarol or warfarin in combination with quinidine sulphate or disopyramide.

\section{Comment}

Warfarin and other anticoagulant agents such as dicoumarol interact with a large variety of drugs. Both an increase and a decrease in anticoagulant action may be observed clinically. Only Haworth and Burroughs ${ }^{1}$ have reported an interaction between disopyramide and warfarin. In contrast with other reports, ${ }^{2}$ we found a decreased anticoagulant effect when dicoumarol or warfarin was combined with quinidine. A decreased effect was also observed in two of the three patients receiving warfarin when disopyramide was added.

The mechanism for the observed need for an increase in anticoagulant dosage after conversion of atrial fibrillation to sinus rhythm is unknown. Nevertheless, that patients treated with quinidine or disopyramide showed the same decrease in anticoagulant effect after conversion suggests that haemodynamic factors might be implicated. In sinus rhythm regular atrial contractions might contribute to increased cardiac output and increased liver blood flow. This might result in an enhanced production of prothrombin and other coagulation factors, requiring a higher anticoagulant regimen. The patient described by Haworth and Burroughs was, in fact, initially hypotensive but recovered after discontinuation of the disopyramide. Thus their patient initially had a low cardiac output that later returned to normal, which also might explain the observed decrease in prothrombin time.

${ }^{1}$ Haworth E, Burroughs AR. Disopyramide and warfarin interaction. $\mathrm{Br}$ Med $\mathcal{F} 1977$;ii :866-7.

${ }^{2}$ Koch-Weser J. Quinidine-induced hypoprothrombinemic hemorrhage in patients on chronic warfarin therapy. Ann Intern Med 1968;68:511-7.

(Accepted 12 fanuary 1983)

Karolinska Hospital, S-104 01 Stockholm, Sweden

CHRISTER SYLVÉN, MD, department of medicine PER ANDERSON, MD, department of clinical pharmacology

Correspondence to: Dr Christer Sylvén.

\section{Effect of doxapram on heavy sedation produced by intravenous diazepam}

Diazepam is widely used to provide sedation during endoscopy, biopsy procedures, and minor surgery. Given intravenously it may cause excessive sedation and ventilatory depression. There is no specific antidote. We carried out a randomised controlled trial of the effects of doxapram in patients heavily sedated with intravenous diazepam.

\section{Patients, methods, and results}

We studied 115 patients undergoing gastroduodenoscopy with intravenous diazepam sedation; no other sedation or premedication was used. None of

Anticoagulant treatment before and after DC conversion of atrial fibrillation (dose given as mean weekly number of tablets (dicoumarol $50 \mathrm{mg}$, warfarin $2.5 \mathrm{mg}$ )), mean weekly thrombotest result (\%), and antiarrhythmic treatment

\begin{tabular}{|c|c|c|c|c|c|c|c|c|c|}
\hline \multirow{2}{*}{$\begin{array}{l}\text { Case } \\
\text { No }\end{array}$} & \multirow{2}{*}{$\underset{\text { (years) }}{\text { Age }}$} & \multirow[b]{2}{*}{ Anticoagulant } & \multicolumn{3}{|c|}{ Mean weekly dose (No of tablets) } & \multicolumn{3}{|c|}{ Mean weekly thrombotest result ( $\%$ ) } & \multirow{2}{*}{$\begin{array}{l}\text {-Antiarrhythmic } \\
\text { treatment }\end{array}$} \\
\hline & & & Before & $p<0.01$ & After & Before & NS & After & \\
\hline $\begin{array}{l}1 \\
2 \\
3 \\
4 \\
5 \\
6 \\
7\end{array}$ & $\begin{array}{l}62 \\
67 \\
49 \\
60 \\
63 \\
70 \\
62\end{array}$ & $\begin{array}{l}\text { Dicoumarol } \\
\text { Dicoumarol } \\
\text { Warfarin } \\
\text { Warfarin } \\
\text { Warfarin } \\
\text { Warfarin } \\
\text { Warfarin }\end{array}$ & $\begin{array}{r}6 \cdot 0 \\
10.5 \\
10.5 \\
13 \cdot 0 \\
14 \cdot 0 \\
14 \cdot 5 \\
13.0\end{array}$ & & $\begin{array}{r}7 \cdot 0 \\
13 \cdot 0 \\
12 \cdot 0 \\
14 \cdot 0 \\
14 \cdot 0 \\
16 \cdot 0 \\
14 \cdot 0\end{array}$ & $\begin{array}{rl}10 & +5 \\
10 & +2 \\
7 & 3 \\
10 & 3 \\
8 & 3 \\
11 & 2 \\
9 & 6\end{array}$ & & $\begin{array}{ll}10 & 4 \\
10 & 2 \\
13 & 4 \\
9 & 2 \\
12 & 1 \\
14 & 2 \\
11 & 3\end{array}$ & $\begin{array}{l}\text { Quinidine } \\
\text { Quinidine } \\
\text { Quinidine } \\
\text { Quinidine } \\
\text { Disopyramide } \\
\text { Disopyramide } \\
\text { Disopyramide }\end{array}$ \\
\hline
\end{tabular}

